\title{
Resonances of Gravitational Tides \\ as a Powerful Energy Source \\ of the Geodynamic Processes in Earth's Crust
}

Victor G. Sibgatulin*, Sergey A. Peretokin and Aleksey A. Kabanov Non-profit Partnership «Ecological Center of Rational Development of Natural Resources» 53-310, Mira, Krasnoyarsk, 660049, Russia

It was proposed a method for the prediction of the occurrence of fourteen day resonances of gravitational tides in the Earth's crust. The data of registration of parameters of tidal gravitational factors including fluctuations of the barycenter in Earth-Moon system in different geophysical fields was presented for the first time. It was given the estimation of the amount of changes in the stress-strain state of the geological environment under the resonances influence. It was substantiated possible directions of using energy of the resonances of gravitational tides in the Earth's crust in oil and gas fields, the earthquake prediction, security of large man-made structures (hydroelectric dams), and the development of theories of single deformation killer waves.

Keywords: resonances, gravitational tides, barycenter, geological environment, earthquake.

Citation: Sibgatulin V.G., Peretokin S.A., Kabanov A.A. Resonances of gravitational tides as a powerful energy source of the geodynamic processes in earth's crust, J. Sib. Fed. Univ. Eng. technol., 2016, 9(2), 146-165, DOI: 10.17516/1999-494X-20169-2-146-165.

(C) Siberian Federal University. All rights reserved

* Corresponding author E-mail address: ec_ropr@mail.ru 


\title{
Резонансы гравитационных приливов - мощный энергетический источник \\ геодинамических процессов в земной коре
}

\author{
В.Г. Сибгатулин, \\ С.А. Перетокин, А.А. Кабанов \\ НП «Экологический центр рационального освоения \\ природных ресурсов» \\ Россия, 660049, Красноярск, пр. Мира, 53-310
}

\begin{abstract}
Предложен способ прогноза времени возникновения резонансов четырнадиатидневных гравитационных приливов в земной коре. Впервые представлены данные регистрации резонансов приливных гравитирующих факторов, включая колебания барицентра системь Земля - Луна в различных геофизических полях. Дана оченка величины изменений напряженнодеформированного состояния геологической среды под влиянием резонансов. Обоснованы возможные направления использования энергии резонансов гравитационных приливов в земной коре в нефтегазовой отрасли, при прогнозе землетрясений, обеспечении безопасности крупных техногенных сооружений (плотин ГЭС), разработке теории возникновения одиночных деформационных волн-убийи.
\end{abstract}

Ключевые слова: резонанс, гравитационный прилив, барицентр, геологическая среда, землетрясение.

\section{Введение}

Ньютон на основе закона всемирного тяготения объяснил природу приливов в морях и океанах. Гравитационные приливы характерны не только для морской среды (где они легко наблюдаются человеком без приборов), но и для земной коры. Современные лазерные интерферометры-деформометры, высокоточные гравиметры и GPS-приемники позволяют регистрировать приливные волны в геологической среде $[1,2]$. При морских приливах вещество перемещается в пространстве, в земной коре приливы приводят только к вертикальным колебаниям частиц горных пород и вызывают изменения тензора напряженно деформированного состояния (НДС) геологической среды [3].

В средних широтах дважды в сутки поверхность Земли и границы раздела внутри земной коры смещаются вдоль радиуса Земли на $30 \div 40$ см [4].

Установлено [3, 4], что приливы имеют сложную структуру: наиболее изучены приливы вдоль экватора (параллелей), образующие бегущую волну. Приливы вдоль меридианов между полюсами и экватором, согласно исследованиям Эри (1845 г.), представляют собой стоячие волны. Приливы делятся на суточные, полусуточные, полумесячные - $14 \div 15$ суток и более длительные, связанные с движением Земли вокруг Солнца [4].

Гравитационные приливы постоянно регистрируются специальной аппаратурой (в том числе лазерными интерферометрами-деформометрами) на геодинамических полигонах РАН и других организаций [5]. Возникновение резонансов гравитационных приливов в земной коре следует из ньютоновской теории тяготения [3].

$$
-147-
$$


В русскоязычной литературе нам не удалось найти примеры проявлений резонансов гравитационных приливов в земной коре. Кроме «классических» приливов на напряжённодеформированное состояние (НДС) геологической среды оказывают влияние и другие циклические гравитирующие факторы. В частности, известно, что вокруг Солнца вращается не центр тяжести планеты Земля, а так называемый барицентр системы Земля - Луна. При этом в связи с различием масс (масса Луны $\approx$ в 81 раз меньше массы Земли) барицентр находится внутри Земли и колеблется на глубине от 1200 до 1900 км от поверхности Земли в течение лунного месяца. Известно, что если центр тяжести физической системы не совпадает с геометрическим центром, то при вращении возникают периодические колебания напряжений (деформаций). Таким образом, помимо гравитационного (приливного) влияния Луны и Солнца литосфера Земли постоянно подвергается волнам сжатия-растяжения за счет изменения положения барицентра. В 2009 г. авторами была обоснована необходимость учета колебаний барицентра при оценке приливных воздействий на геологическую среду [6]. Для расчёта координат барицентра использовался программный комплекс Калифорнийского технологического института (США) для эфемерид [7].

\section{Нормировка приливных факторов для оценки воздействия на напряжённо-деформированное состояние геологической среды}

В течение лунно-солнечного месяца расстояние Земля - Луна изменяется примерно на 40 тыс. км, фазы Луны изменяются от полнолуния до отсутствия Луны на небосводе («черная» Луна), а барицентр системы Земля - Луна колеблется примерно на 700 км внутри литосферы верхней мантии. Для того чтобы увязать упомянутые гравитирующие факторы в единую систему отсчета, была использована нормировка параметров гравитирующих факторов в интервале от нуля до единицы $(0 ; 1)$. При этом за единицу принято максимальное значение параметра в течение года, а за 0 - минимальное годовое значение.

В результате получены графики изменения во времени нормированных к единице параметров гравитирующих факторов (расстояние Земля - Луна, фазы Луны, расстояние барицентра от поверхности Земли и от наблюдателя, т.к. барицентр в любой точке не только колеблется по вертикали, но и «обегает» земной шар вдоль параллелей).

При этом максимальное влияние на НДС геологической среды земного шара оказывают колебания барицентра в интервале $\pm 28-30^{\circ}$ относительно плоскости эклиптики.

На рис. 1 представлен фрагмент нормированных параметров приливных гравитирующих факторов для наблюдателя, находящегося в пункте с координатами $53^{\circ}$ с.ш. и $91^{\circ}$ в.д.

Приливные волны способны входить в резонанс между собой при известных условиях близости частоты и фазы. Длиннопериодные (14-15 суток) гравитационные приливы удовлетворяют этим условиям, поэтому графики гравитирующих факторов образуют точки пересечения, которые мы рассматриваем в качестве индикатора резонансов гравитационных приливов. Время резонансов можно рассчитать с помощью аппарата MatLab как точку пересечения двух функций X и Y:

$$
\begin{aligned}
& X=[] ; \\
& Y=[] ;
\end{aligned}
$$




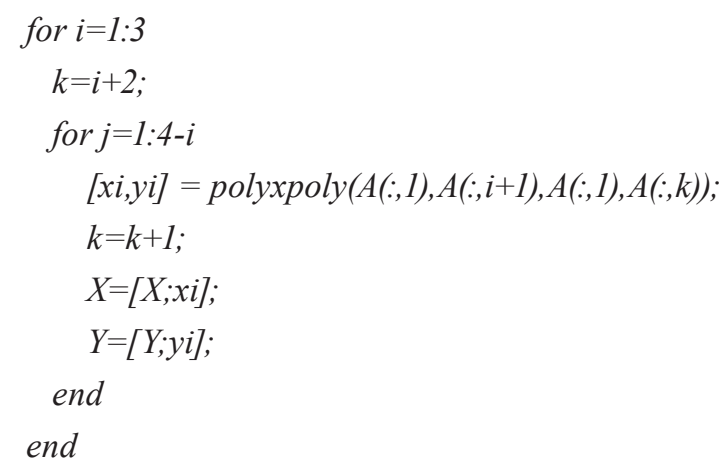

При подготовке рисунков мы для наглядности пользовались графической формой. Принцип графического прогноза резонансов различных гравитирующих факторов представлен на рис. 1. В дальнейшем изложении на всех рисунках использовались условные обозначения, принятые для рис. 1.

Следует отметить, что основной результат наших исследований - прогнозирование и регистрация резонансов гравитационных приливов в различных геофизических полях.

\section{Примеры проявления резонансов гравитационных приливов}

Обоснованность предположения о приуроченности пересечений графиков гравитирующих факторов к резонансам приливов подтверждена многолетними экспериментальными дан-

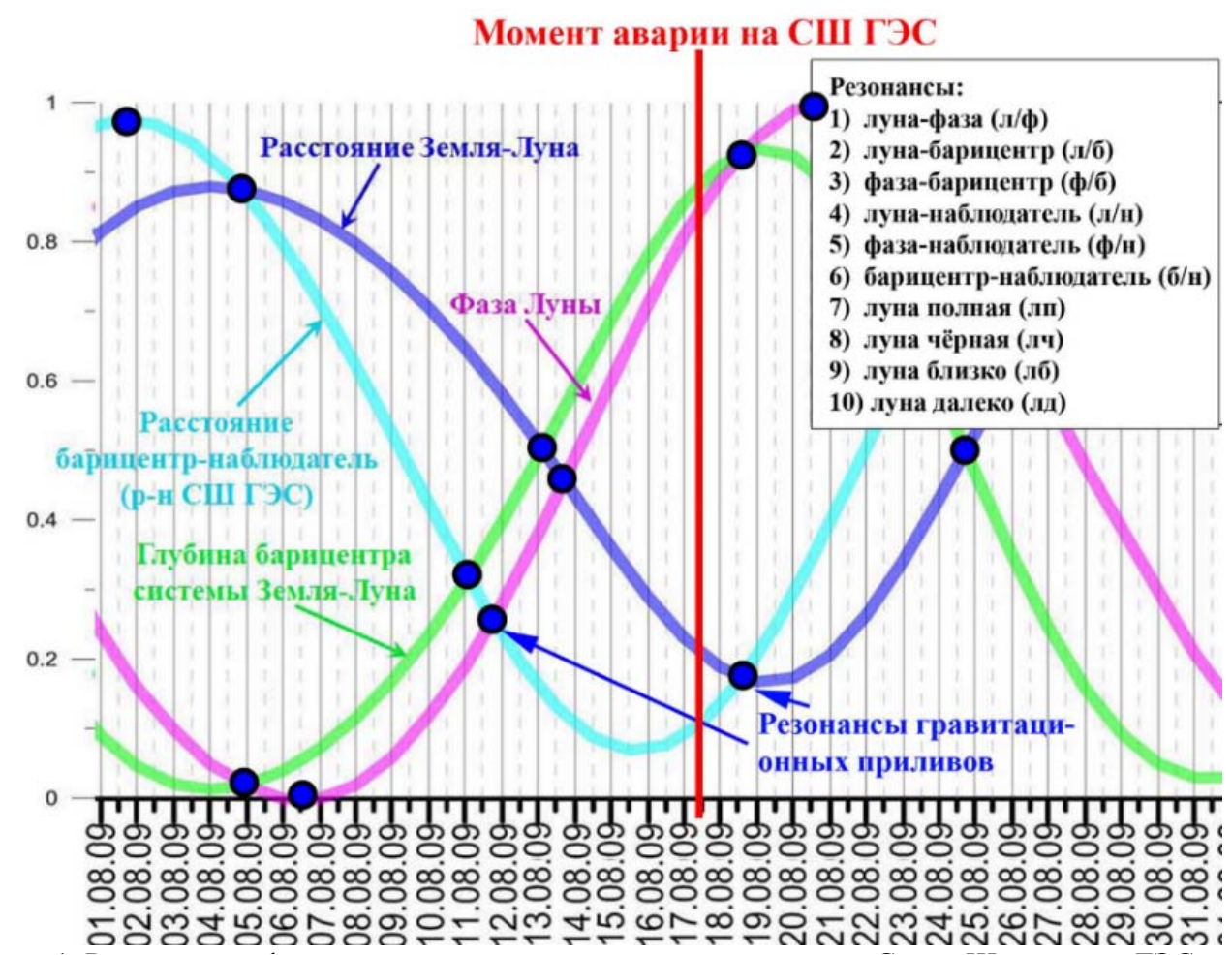

Рис. 1. Резонансы деформационных приливов и момент аварии на Саяно-Шушенской ГЭС на реке Енисей (Красноярский край, 17.08.2009) 
ными. В частности, на рис. 2 представлена корреляция между резонансами гравитационных приливов, сейсмической, электромагнитной эмиссией и эмиссией радона в подземных водах.

При геодинамическом мониторинге в 2007-2015 гг. на п-ове Камчатка, о. Сахалин и в Алтае-Саянской области постоянно наблюдаются резонансы гравитационных приливов $[2,8]$.

Принципиальное отличие позиции авторов от других исследователей заключается в допущении в качестве энергетического источника напряжённо-деформированного состояния (НДС) геологической среды не только лунно-солнечных приливов, но и колебаний барицентра системы Земля - Луна. При этом основное энергетическое воздействие на геологическую среду оказывают не сами приливы, а резонансы приливных факторов различных типов, включая взаимодействие лунно-солнечных приливов с колебаниями барицентра. На рис. 3-8 изображены примеры проявления резонансов гравитационных приливов в различных геофизических полях.

Как видно из рис. 2, структура ЕИЭМПЗ, эмиссии радона, сейсмической эмиссии чётко коррелируются с пересечением графиков гравитирующих факторов, т.е. с резонансами гравитационных приливов. Во всех регионах Сибири и Дальнего Востока эта закономерность проявления резонансов приливов в структуре геофизических данных устойчиво фиксируется.

Сопоставление времени катастрофических $(\mathrm{M} \geq 6.0)$ землетрясений на земном шаре за XX и XXI вв. с расчетными резонансами гравитационных приливов для каждого сейсмического

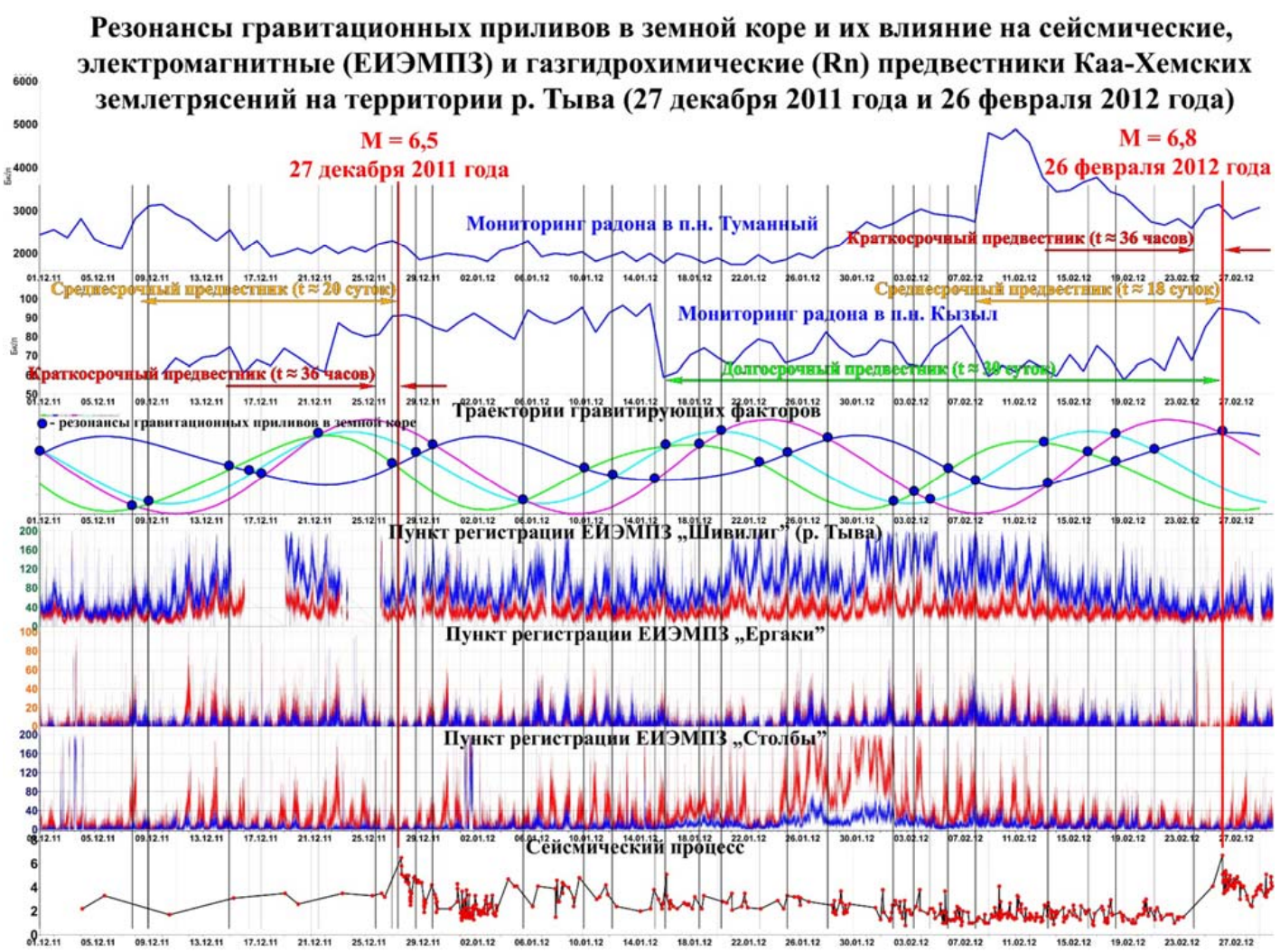

Рис. 2. Корреляция между структурой естественного импульсного электромагнитного поля Земли, структурой эмиссии радона и расчетными резонансами деформационных приливов 


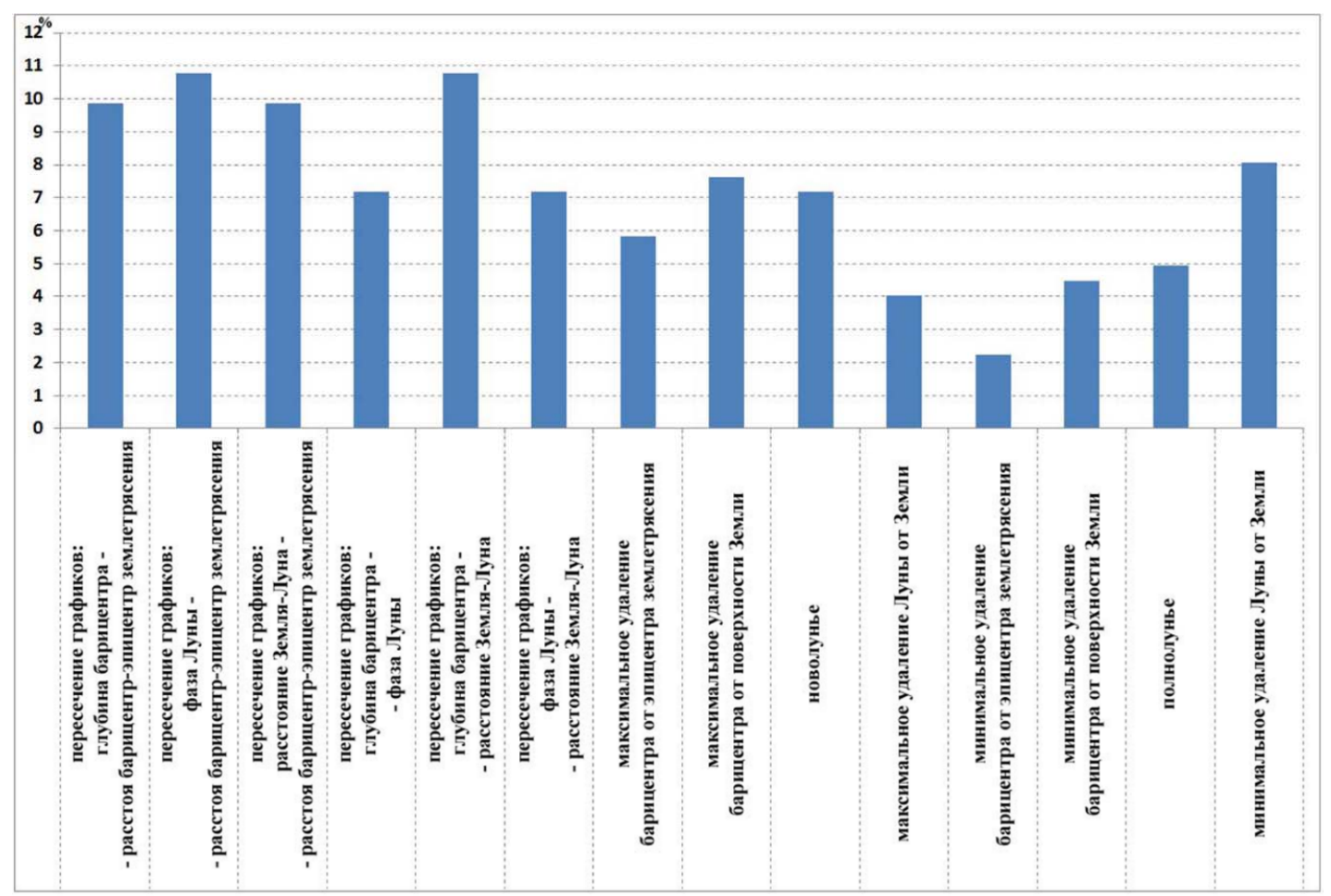

Рис. 3. Распределение частоты совпадения моментов ( \pm 12 часов) сильных $(\mathrm{M} \geq 6.0)$ землетрясений в $\mathrm{XX}$-XXI вв. с временами различных типов резонансов гравитационных приливов

события позволяет утверждать, что около 80 \% катастрофических землетрясений по времени с точностью \pm 12 ч совпадают с расчетными резонансами [9].

На рис. 3 представлена приуроченность выборки катастрофических землетрясений к определённым типам резонансов (пересечениям графиков различных гравитирующих факторов).

Тесная корреляция (около 80 \%) между временем расчетных резонансов и срабатыванием сейсмических очагов зафиксирована в Алтае-Саянском сейсмоактивном регионе, на Камчатке и Сахалине для землетрясений с $\mathrm{M} \geq 5.0$.

Таким образом, резонансы гравитационных приливов являются триггерами подавляющего большинства сильных и катастрофических землетрясений на земном шаре. Помимо сейсмических очагов резонансы приливов оказывают влияние и на другие геологические объекты. В процессе исследований выявлено влияние резонансов на такие объекты, как скальные массивы, флюидонасыщенные коллекторы в земной коре, а также техногенные сооружения (плотины ГЭС).

Рис. 4 демонстрирует корреляцию амплитуд спектра сейсмических шумов гранитоидного массива (в районе г. Красноярска) с прогнозными резонансами. Как видно, при неучёте колебаний барицентра невозможно объяснить аномалии $(\mathrm{A}, \mathrm{B}, \mathrm{C})$ амплитуды спектров сейсмических шумов в гранитоидном массиве.

В последние 5 лет (судя по публикациям) усилился интерес исследователей к оценкам влияния гравитационных приливов на геологическую среду. В частности, в литературе анализи- 


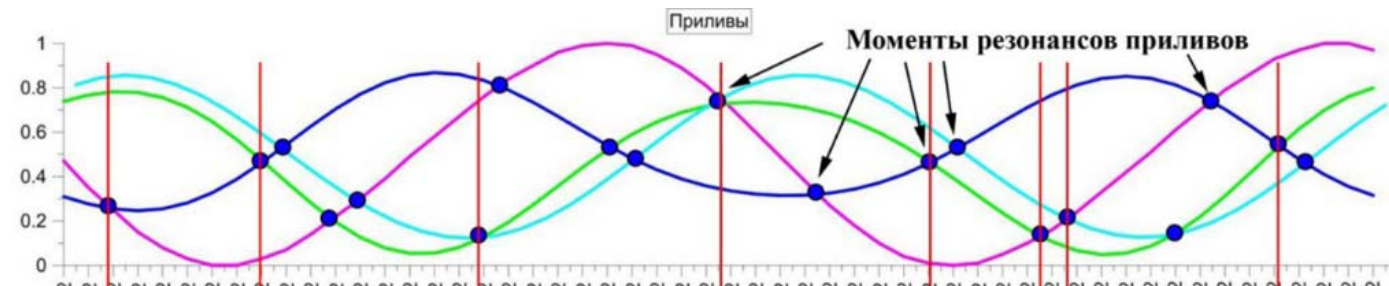

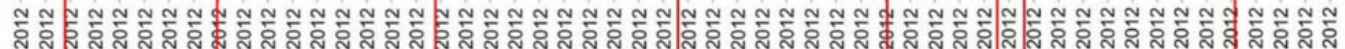

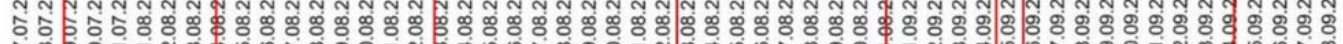

ลึ

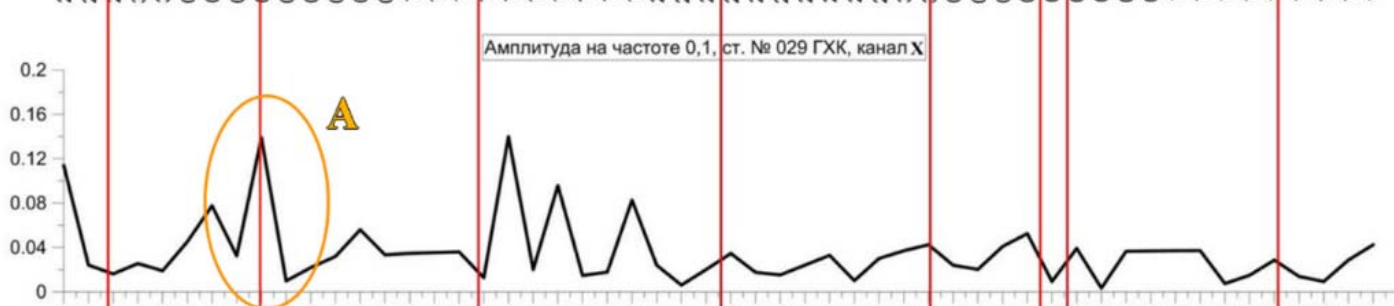

药 ำ

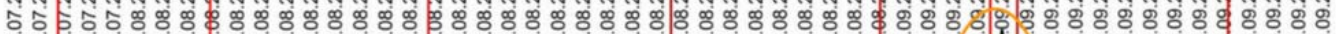

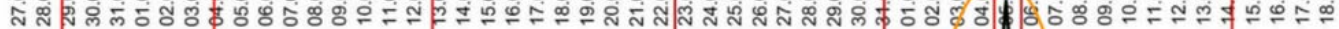

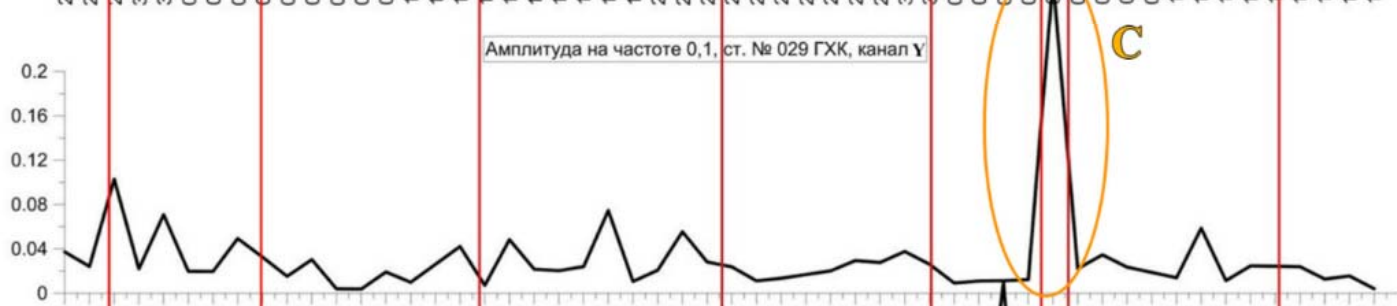

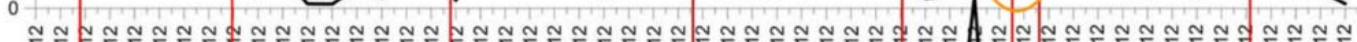

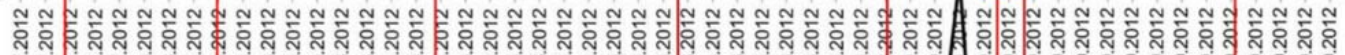

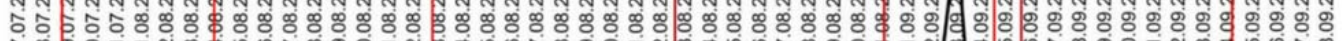

సั่

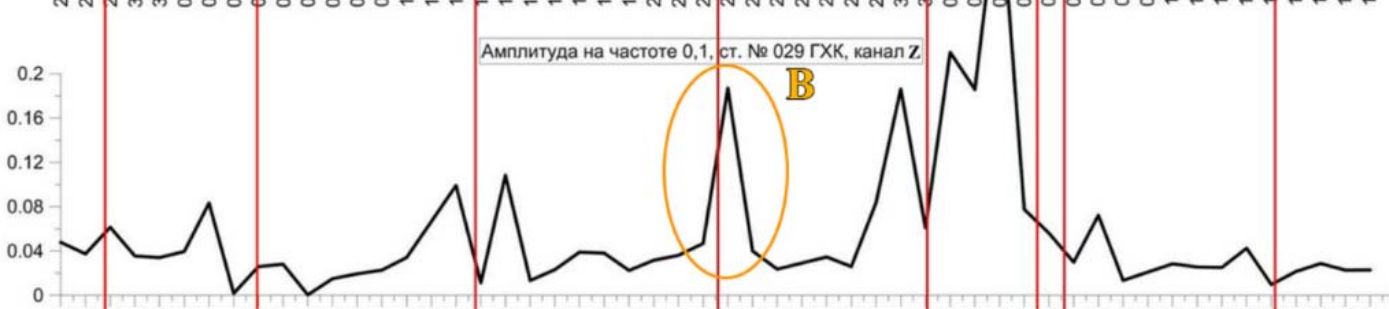

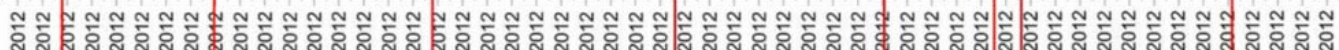

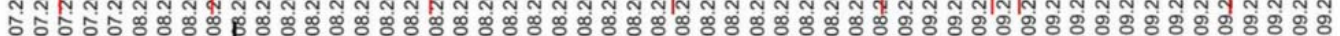

ลั่

Рис. 4. Амплитуды спектра сейсмических шумов гранитоидного массива и резонансы гравитационных приливов. Аномалии спектра шумов на каналах X, Y, Z (А, В, С и др.) обусловлены резонансом 14-15-дневных лунно-солнечных приливов и колебанием барицентра системы Земля - Луна

руется влияние приливов на поведение флюидных (водоносных) систем [10]. Много внимания уделяется вкладу приливов в аномальное гравитационное поле Земли [11 и др.].

Однако при этом исследователи игнорируют вклад колебаний барицентра в формирование НДС геологической среды. Неучёт резонансов гравитационных приливов не позволяет удовлетворительно объяснить результаты экспериментов, выполненных при решении различных задач (от прогноза землетрясений до оценки НДС геологической среды при ГГД мониторин- 
ге и др.). Достаточно сопоставить влияние резонансов двухнедельных приливов с откликом флюидонасыщенных коллекторов [10] (рис. 5), чтобы убедиться, что именно резонансы гравитационных приливов формируют поле напряжений в геологической среде, в частности во флюидонасыщенных коллекторах.

Особенности циклических изменений поля напряжений на геодинамическом полигоне в районе С.-Петербурга [11 и др.], представленные на рис. 6, свидетельствуют о тесной (прак-

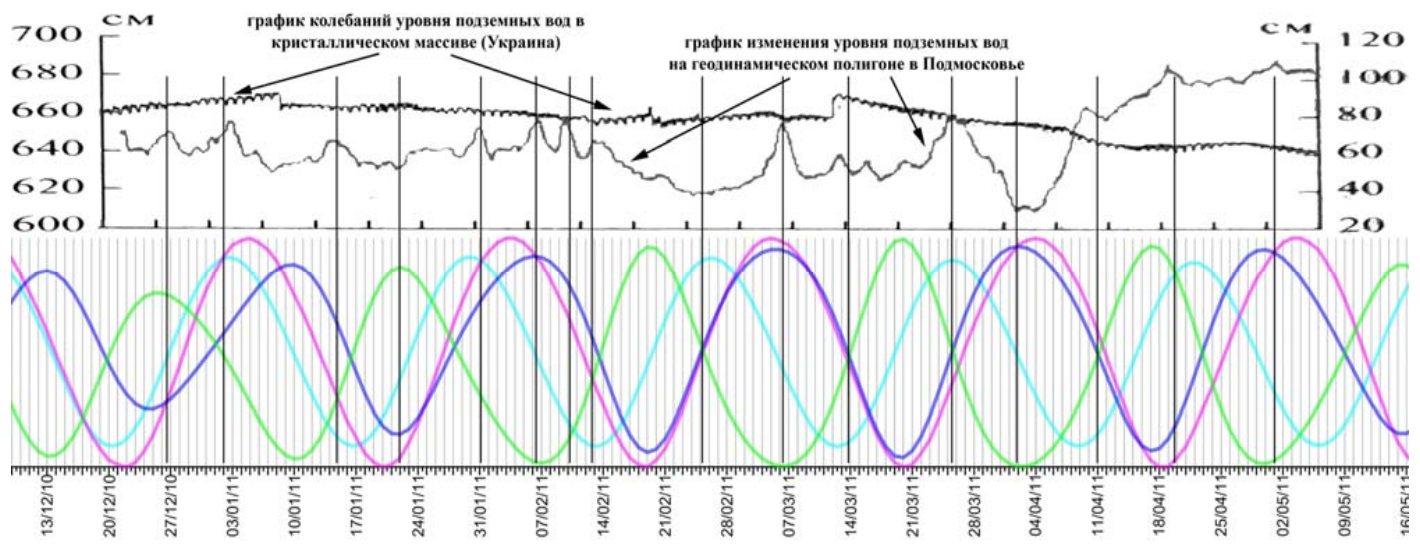

Рис. 5. Отклик флюидонасыщенных коллекторов на лунно-солнечные приливы (интерпретация графиков, представленных в статье А.Н. Бесединой и др. [10])*

*Колебания уровня подземных вод в кристаллическом массиве незначительны, тем не менее и в этом случае наблюдается корреляция с резонансами приливов

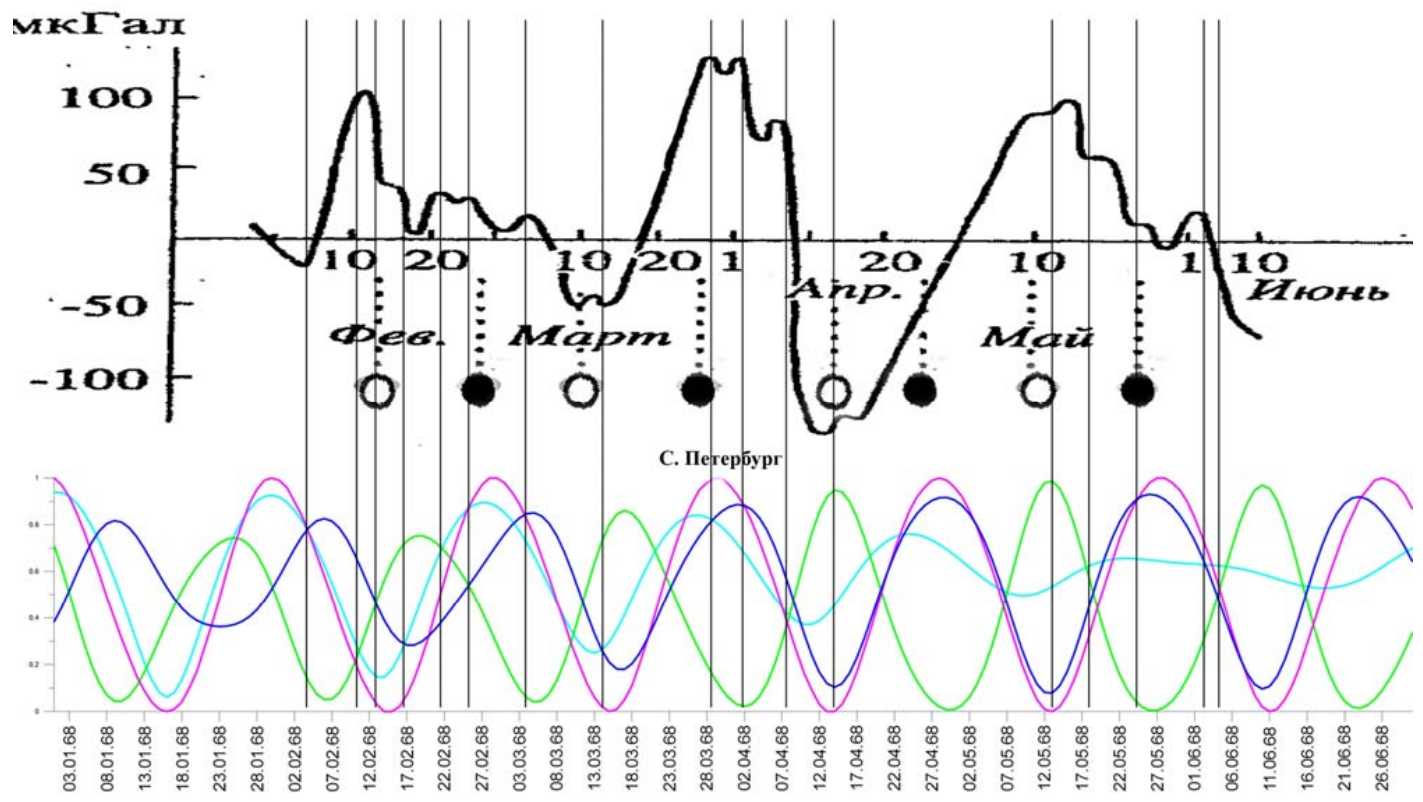

Рис. 6. Сопоставление данных регистрации приливов сейсмометром в районе С.-Петербурга [11] со временем расчётных резонансов 
тически 100\%-ной) корреляции с резонансами приливов. Все особенности поля напряжений соответствуют расчётным точкам возникновения резонансов.

Резонансы приливов оказывают влияние на НДС крупных техногенных объектов (плотины ГЭС и т.д.). На рис. 7 и 8 представлена наша интерпретация данных о колебаниях плотины в Дагестане (СВАН-диаграмма взята из доклада ИФЗ РАН на конференции «Гальперинские чтения - 2013»), а также колебаний секции плотины в Красноярском крае (исходные данные из отчёта ИФЗ РАН за 2012 г. по геодинамическому мониторингу Саяно-Шушенской ГЭС). Как видно, в НДС плотин ощутимый вклад вносят резонансы гравитационных приливов. К сожалению, влияние резонансов гравитационных приливов на безопасность крупных техногенных сооружений не учитывается. Необходимо пересмотреть принцип организации геодинамического мониторинга плотин, долговременных хранилищ радиоактивных отходов и других экологически опасных объектов.

В частности, авторы рекомендовали (2013 г.) при модернизации сети геодинамического мониторинга ГХК в районе Красноярск не только обеспечить мониторинг землетрясений и их

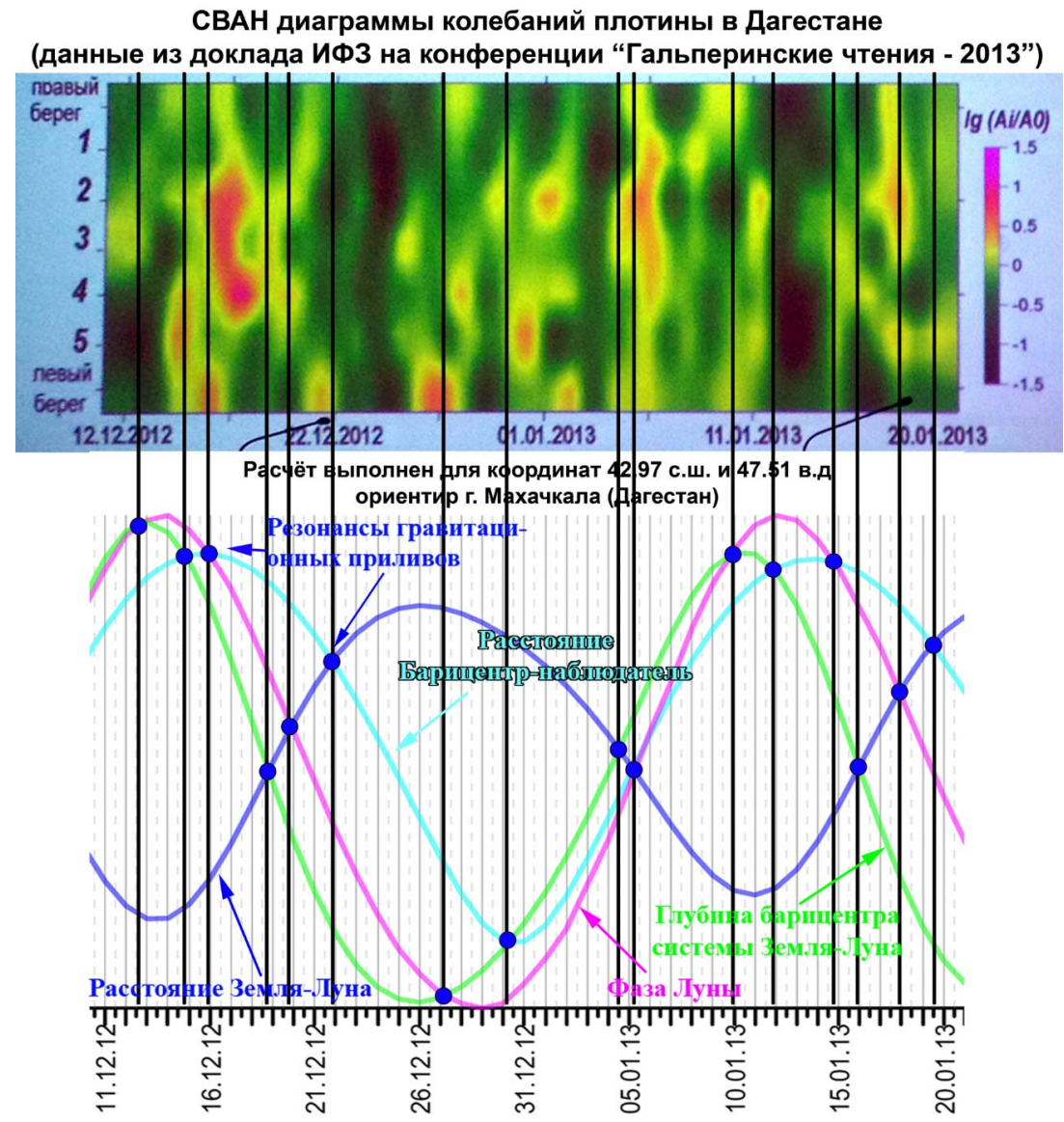

Рис. 7. Интерпретация природы аномалий СВАН-анализа собственных колебаний плотины ГЭС в Дагестане. Наблюдается явная корреляция структуры СВАН-диаграммы с резонансами гравитационных приливов 


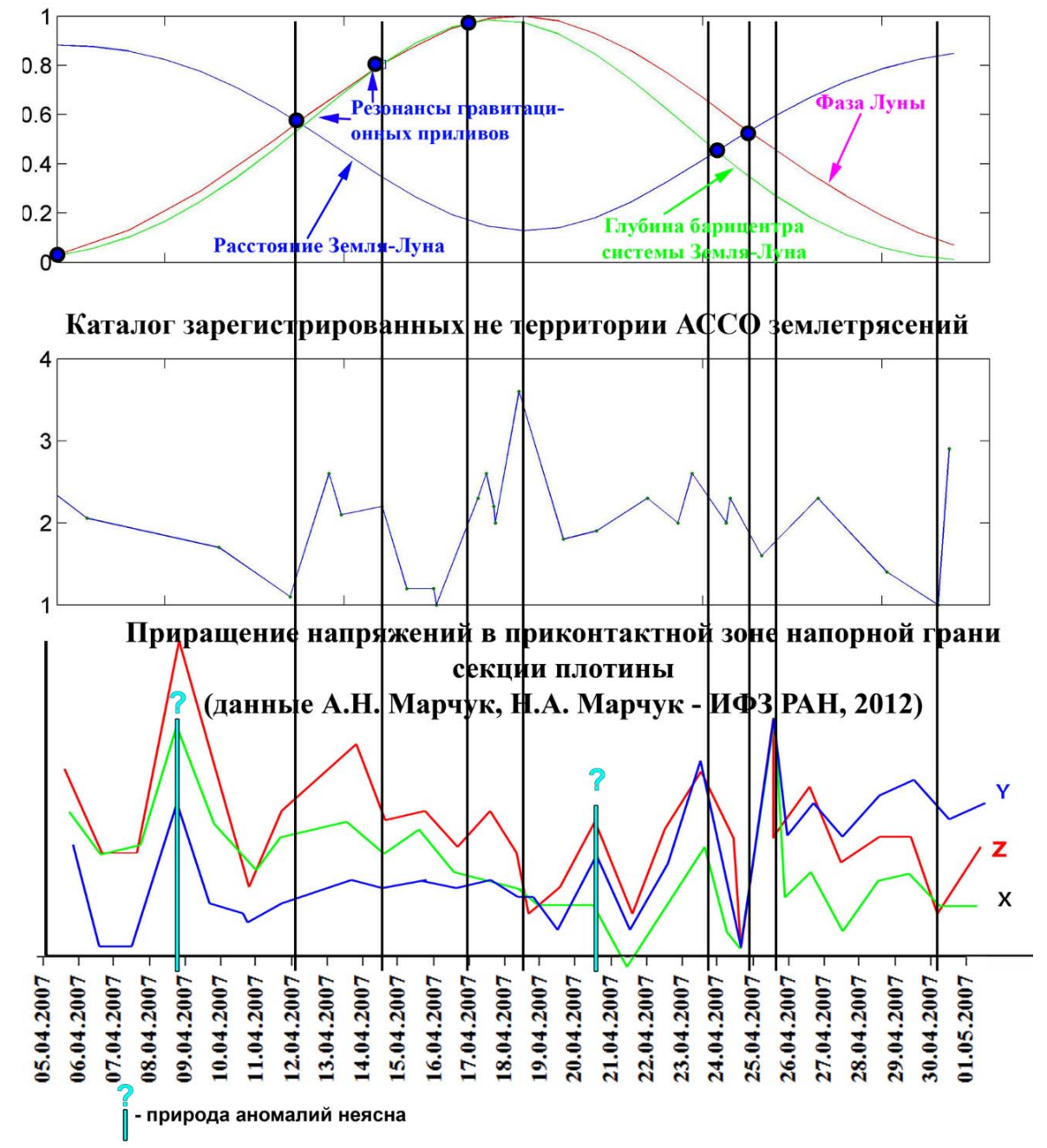

Рис. 8. Интерпретация природы напряжений одной из секций плотины (март 2014 г.)

влияния на техногенные объекты, но и одновременно контролировать медленные волны деформации в геологической среде, которые, по нашим наблюдениям, также генерируются резонансами гравитационных приливов. Известная техногенная катастрофа на Саяно-Шушенской ГЭС (17 августа 2009 г.), вероятно, вызвана резонансом плотины и одиночной волны деформации $[8,12]$.

\section{Реакция флюидных нефтегазовых объектов на резонансы приливов}

В нефтегазовой отрасли резонансы приливов могут использоваться для прямых поисков нефтегазовых залежей (НГЗ) [12,13].

В НГЗ в результате резонанса 14-15-дневных приливов возникают стоячие волны в частотном диапазоне от долей до нескольких Гц $(0,1 \div 3,0$ Гц) в зависимости от параметров НГЗ (мощность залежи, её протяженность, флюидонасыщенность) (рис. 9) [13]. Регистрируя на поверхности собственные низкочастотные колебания НГЗ, можно установить местоположение залежи. 


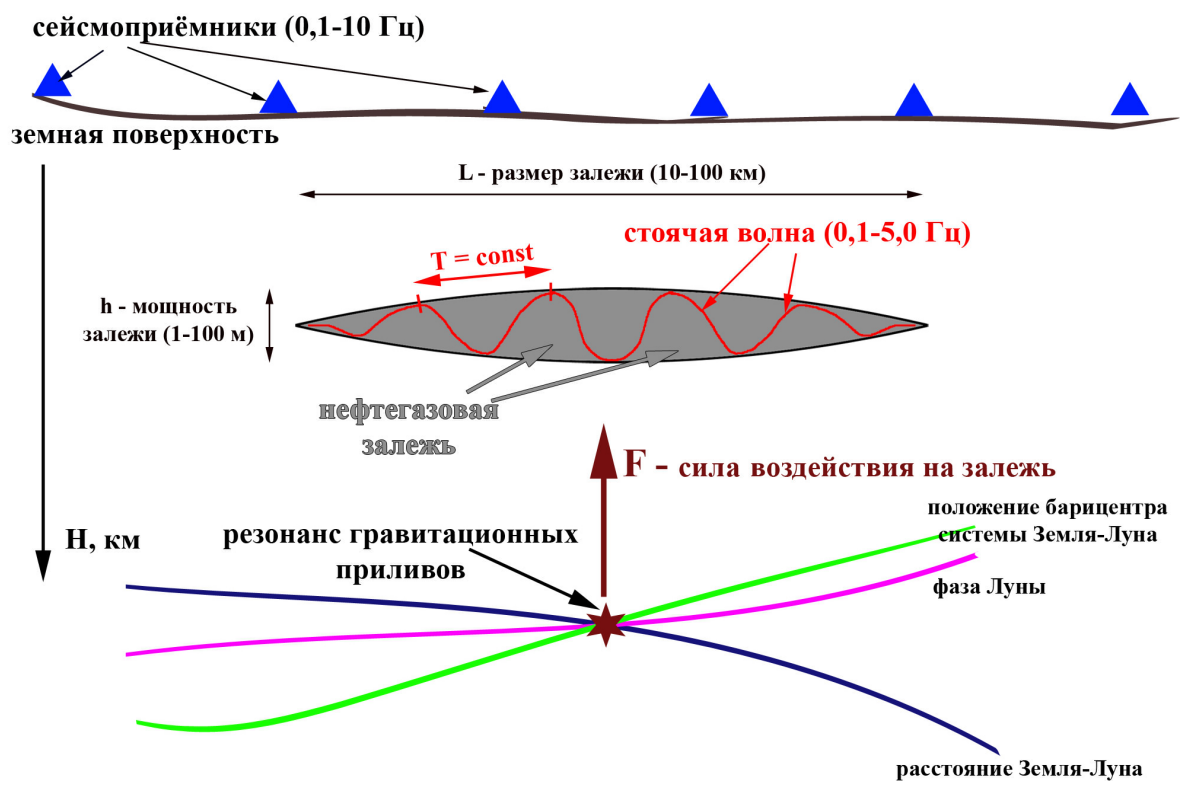

Рис. 9. Возникновение стоячих волн в нефтегазовых залежах под влиянием резонанса гравитационных приливов

Амплитудно-фазовые параметры резонансов гравитационных приливов различных типов в земной коре недостаточно исследованы.

Глубина проникновения деформационных волн, вызванных гравитационными резонансами, вероятно, более 30 км, т.е. охватывает земную кору, литосферу и, возможно, мантию (до 2000 км), т.к. в течение «лунного» месяца барицентр системы Земля - Луна перемещается внутри тела Земли на 700 км (от 1200 до 1900 км от поверхности).

Экспериментально установлено, что резонансы гравитационных приливов усиливают собственные колебания $(0,1 \div 5,0$ Гц) нефтегазовых залежей, что позволяет использовать их в качестве энергетического источника для прямых поисков нефти и газа. На этом принципе разработана и прошла апробацию технология «Флюидная резонансная сейсморазведка - Регистрация приливных воздействий на нефтегазовые залежи» (ФРС-РПВНГЗ) [14].

Технология ФРС основана на энергии резонансов гравитационных приливов, т.е. используется разновидность природного невзрывного источника волновых процессов в земной коре. В этом её принципиальное отличие от «пассивной» низкочастотной сейсморазведки $[15,16]$.

В течение 2010-2015 гг. проведены полевые эксперименты на четырёх площадях на Сибирской платформе с различными типами коллекторов [14]:

1) трещинно-кавернозный коллектор;

2) терригенный нефтегазоносный коллектор мощностью от одного до 10-20 м;

3) газонасыщенный коллектор мощностью от 1-2 до 50 м.

Наиболее чётко фиксируются аномалии спектров колебаний газовых залежей (рис. 10 и 11).

На площади с недостаточно изученной нефтегазоносностью (одна скважина) в бассейне p. Подкаменная Тунгуска получены чёткие аномалии, физическая природа которых, вероятно, связана с нефтегазовыми залежами (рис. 12). 
Газовое месторождение в Приангарье

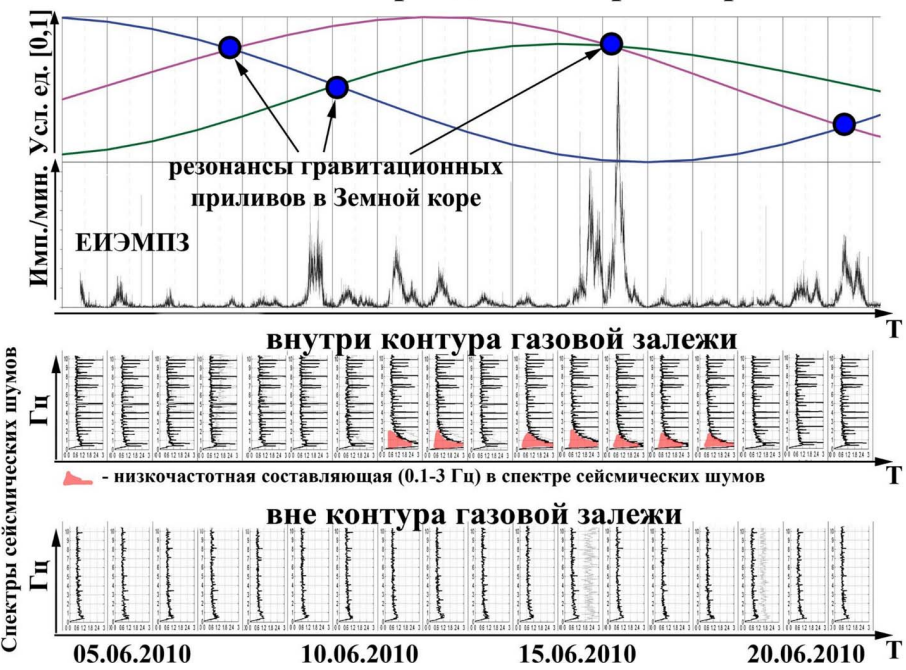

Рис. 10. Реакция газового пласта мощностью около 50 м на резонансы приливов

\section{Газовое месторождение в Иркутской области 16.03.2016}

18.03.2016 19.03.2016
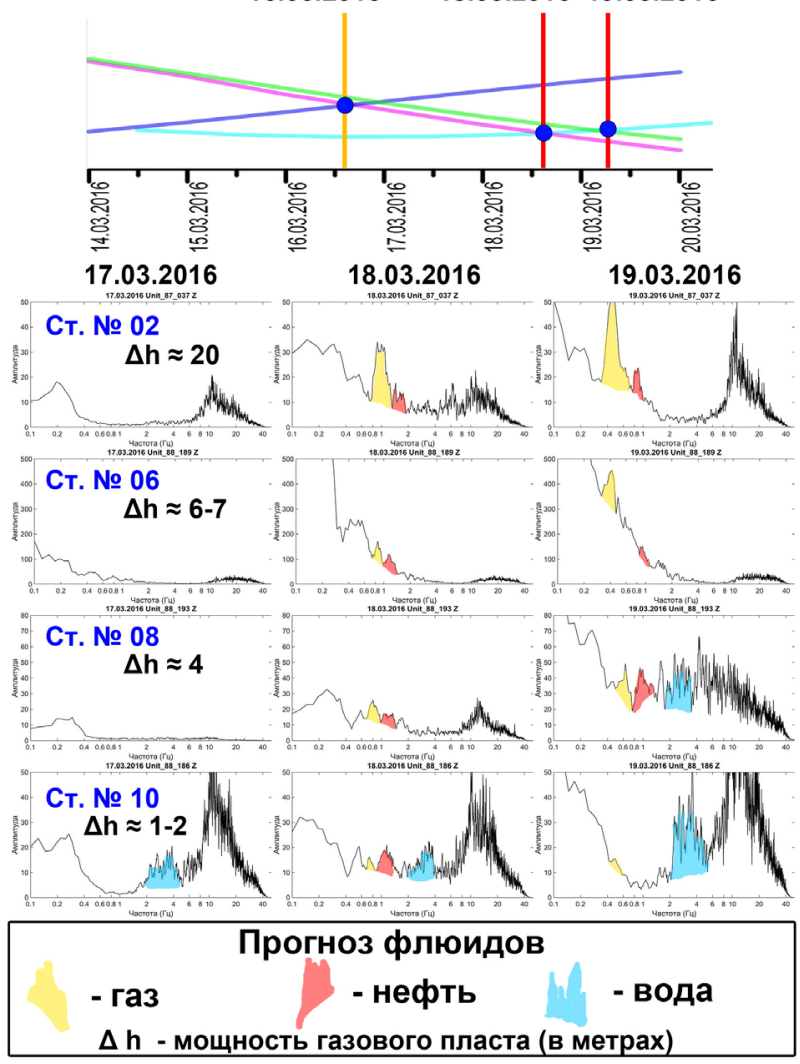

Рис. 11. Реакция газового пласта мощностью от 1 до 20 метров на резонанс приливов* *Резонансы 18.03.2016 и 19.03.2016 обусловили максимум амплитуды спектра сейсмических шумов над газовой залежью 

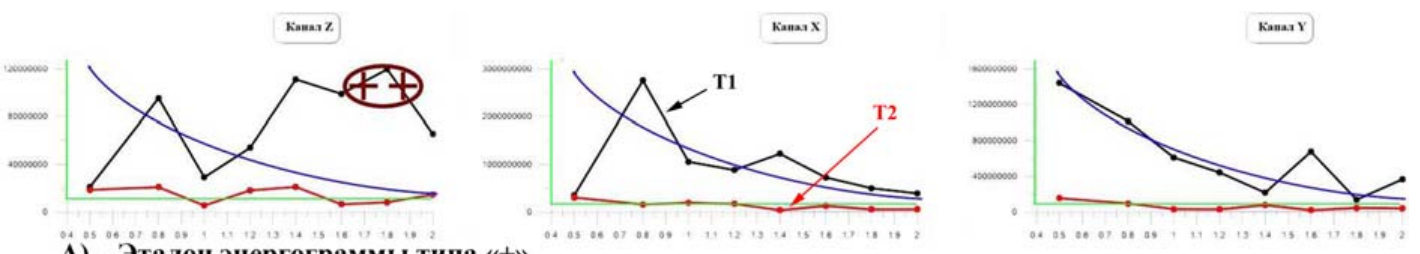

А) - Эталон энергограммы типа «+»
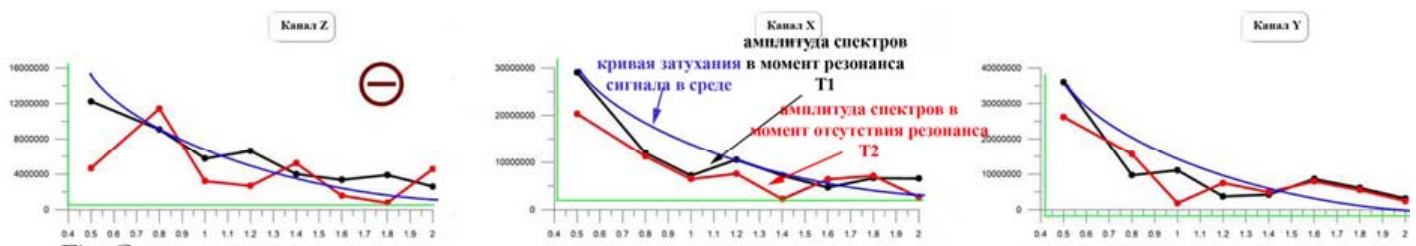

Б) - Эталон энергограммы типа «-»
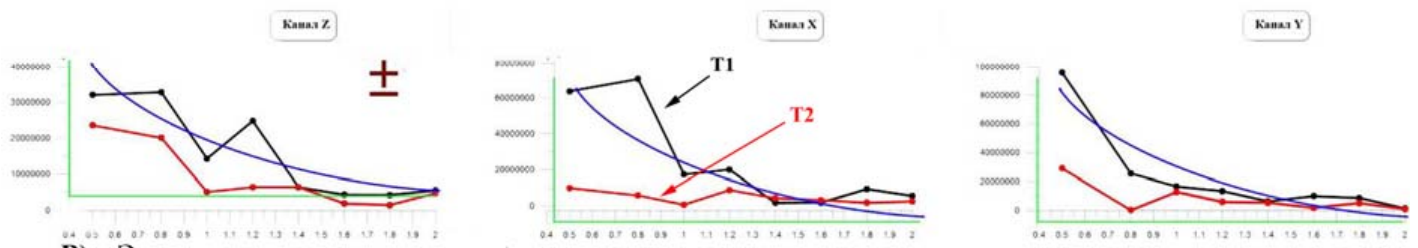

В) - Эталон энергограммы типа «土»

Рис. 12. Типы энергограмм сейсмических шумов на одной из нефтегазовых площадей в бассейне Подкаменной Тунгуски (по оси абсцисс - частота в Гц; по оси ординат - амплитуда спектров сейсмических шумов); Т1 - день, соответствующий резонансу приливов, Т2 - безрезонансный день* *При наличии НГЗ регистрируется чёткая разница в амплитудах спектров сейсмических шумов, предложен алгоритм прогноза наличия или отсутствия НГЗ: А, Б, В

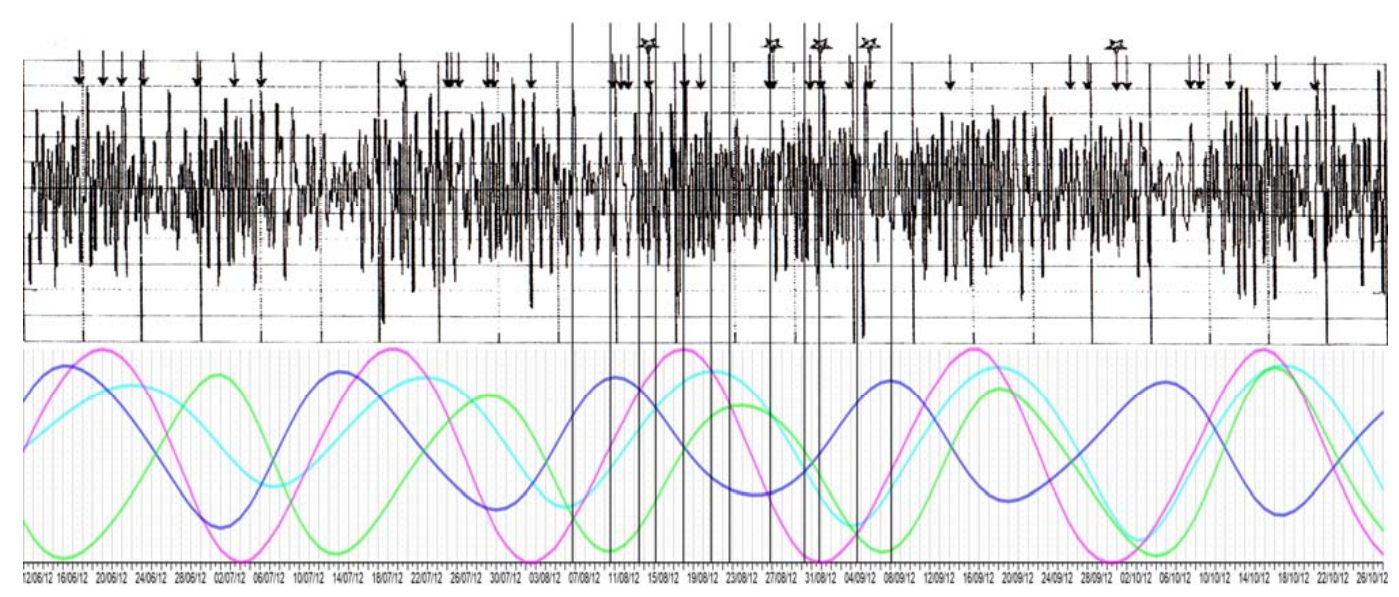

Рис. 13. Сопоставление литосферных деформаций в Крыму (по данным Б.Г. Пустовитенко [5]) с различными приливными факторами и их резонансами*

*Структура литосферных деформаций контролируется не только приливными факторами, но и их резонансами. Для демонстрации связи структуры литосферных деформаций с резонансами приливов на рисунке проведены прямые линии, которые любой читатель может провести через все возможные точки резонансов гравитирующих факторов самостоятельно и убедиться в тесной корреляции структуры литосферных деформаций с временными интервалами между резонансами 


\section{Оценка напряжений, возникающих при резонансах приливов}

Как уже отмечалось, в 2010-2014 гг. авторами предложена графическая методика (см. рис. 1) прогнозирования времени резонансов гравитационных приливов [8]. Однако величина напряжений, которая возникает при этом в геологической среде, оставалась неясной, так как теория недостаточно разработана. Известная программа ETERNA [17] позволяет оценивать напряжения, возникающие в геологической среде при прохождении приливных волн, но она пока не опробована для расчёта напряжений, появляющихся при резонансах приливов.

В условиях отсутствия надёжных теоретических оценок только экспериментальные данные позволяют оценить величину возможных напряжений при возникновении резонанса.

На рис. 14 и 15 представлены результаты регистрации давления и температуры в скважинах на газовом месторождении в Сибири, в пределах которого эффективная мощность газоносного пласта колеблется от 1-2 до 20-30 м.

Анализ рис. 14 и 15 позволяет оценить величину возникающих в горных породах на глубине около 3000 м напряжений при различных типах резонансов. Максимальные отклонения графиков давления связаны с резонансами барицентра и фазы Луны - от 10-12 (рис. 15) до 4-5 \% (рис. 14) от уровня горного давления.

К сожалению, количественная оценка величин колебаний давления в упомянутых скважинах (рис. 14 и 15) в результате воздействия резонансов искажена технологическими процессами (изменение диаметра, смена режимов отбора жидкости через штуцер). При гидропрослушивании скважин влияние техногенных факторов можно минимизировать.
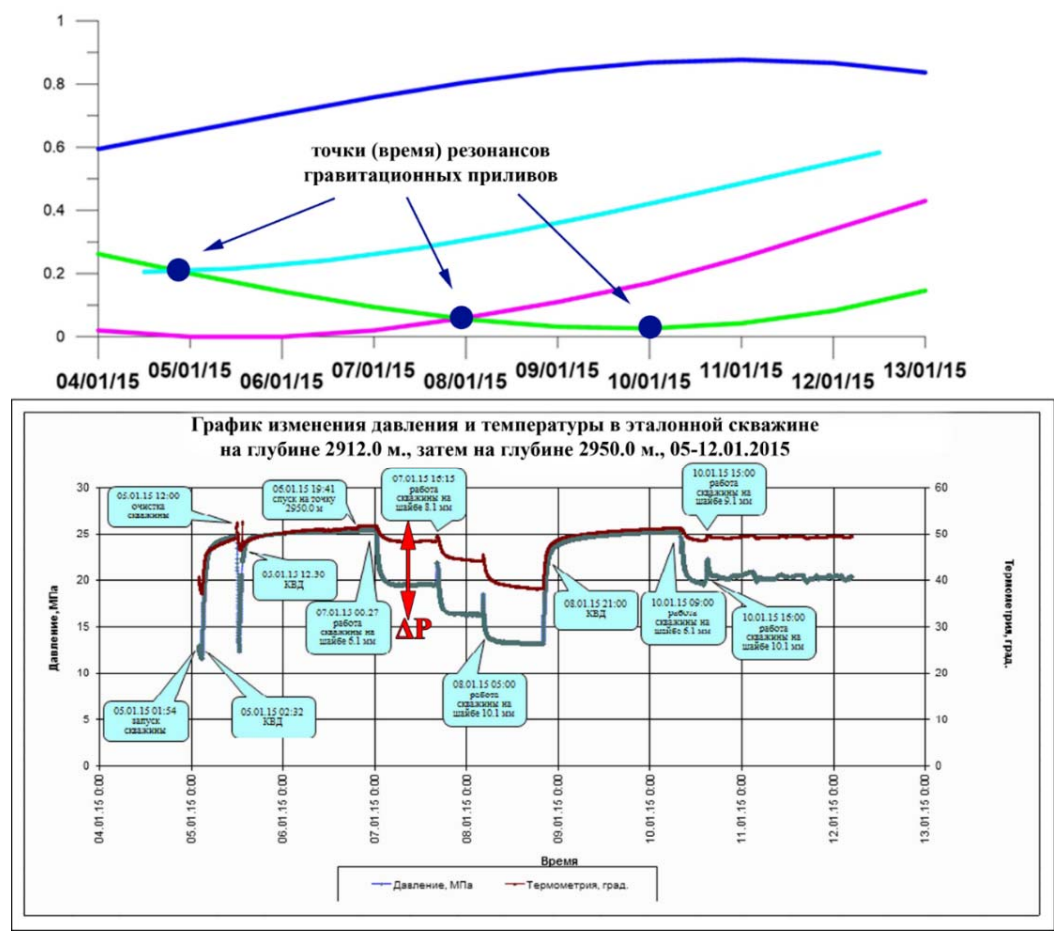

Рис. 14. Колебания давления и температуры в скважине под влиянием резонанса приливов $(\Delta \mathrm{P} \approx 10$ атм. при $\mathrm{P}_{0} \approx 250$ атм. или $\Delta \mathrm{P} \pm 4-5 \%$ от нормального горного давления) 


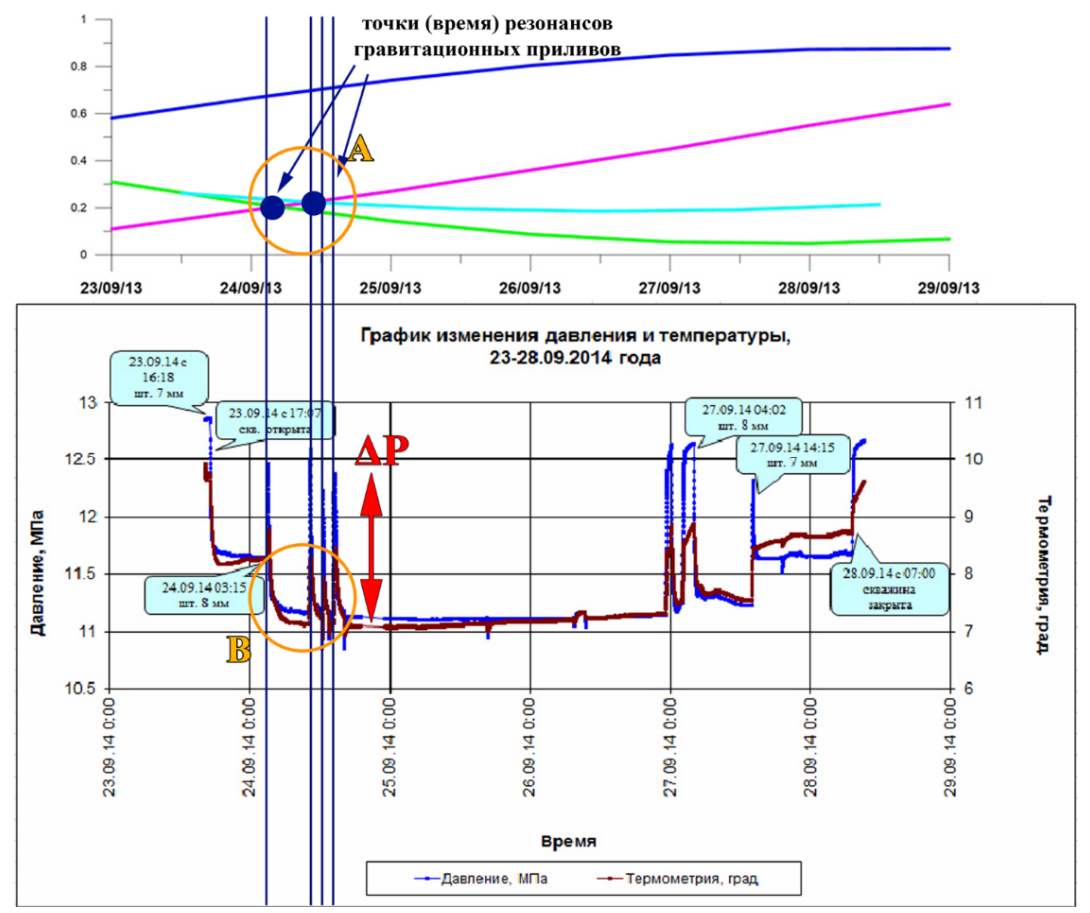

Рис. 15. Колебания давления и температуры в скважине (зона В) под влиянием резонанса приливов (зона А) ( $\Delta \mathrm{P} \approx 10-15$ атм. при $\mathrm{P}_{0} \approx 110$ атм. или $\Delta \mathrm{P} \pm 10-12 \%$ от нормального горного давления)

С согласия ООО «Альтаир» (г. Томск) мы публикуем сопоставление данных гидропрослушивания одной из скважин на месторождении «Самотлор» с резонансами гравитационных приливов (рис. 16).

Скважина с 28.09.2011 по 25.10.2011 г. находилась в состоянии покоя - велась непрерывная (через 2-3 с) регистрация температуры и давления на уровне нефтяного пласта (мощность около 10 м на глубине 1800 м). На рис. 16 чётко прослеживается связь между аномалиями пластового давления в течение суток с расчётными резонансами гравитационных приливов. Характерное «разрастание» давления в течение суток соответствует возбуждению «стоячей волны» в нефтяном пласте. Максимальная амплитуда волны совпадает со временем резонанса, а амплитуда колебаний давления составляет около 1,5 атм. (при уровне горного давления около 125 атм.). Таким образом, резонанс гравитационных приливов оказывает дополнительное воздействие на нефтяной пласт с силой до 1,5 атм. или 1,5 \% от горного давления.

Соответственно, возможные колебания напряжений (деформаций) в скважинах под влиянием различного типа резонансов гравитирующих факторов по экспериментальным данным составляют от 1,5 до 5 \% от горного давления.

\section{Влияние колебаний барицентра системы Земля - Луна на геологическую среду}

Учитывая, что барицентр системы Земля - Луна в течение синодического месяца колеблется в мантии Земли на глубине от 1200 до 1900 км от поверхности, резонансы приливов 


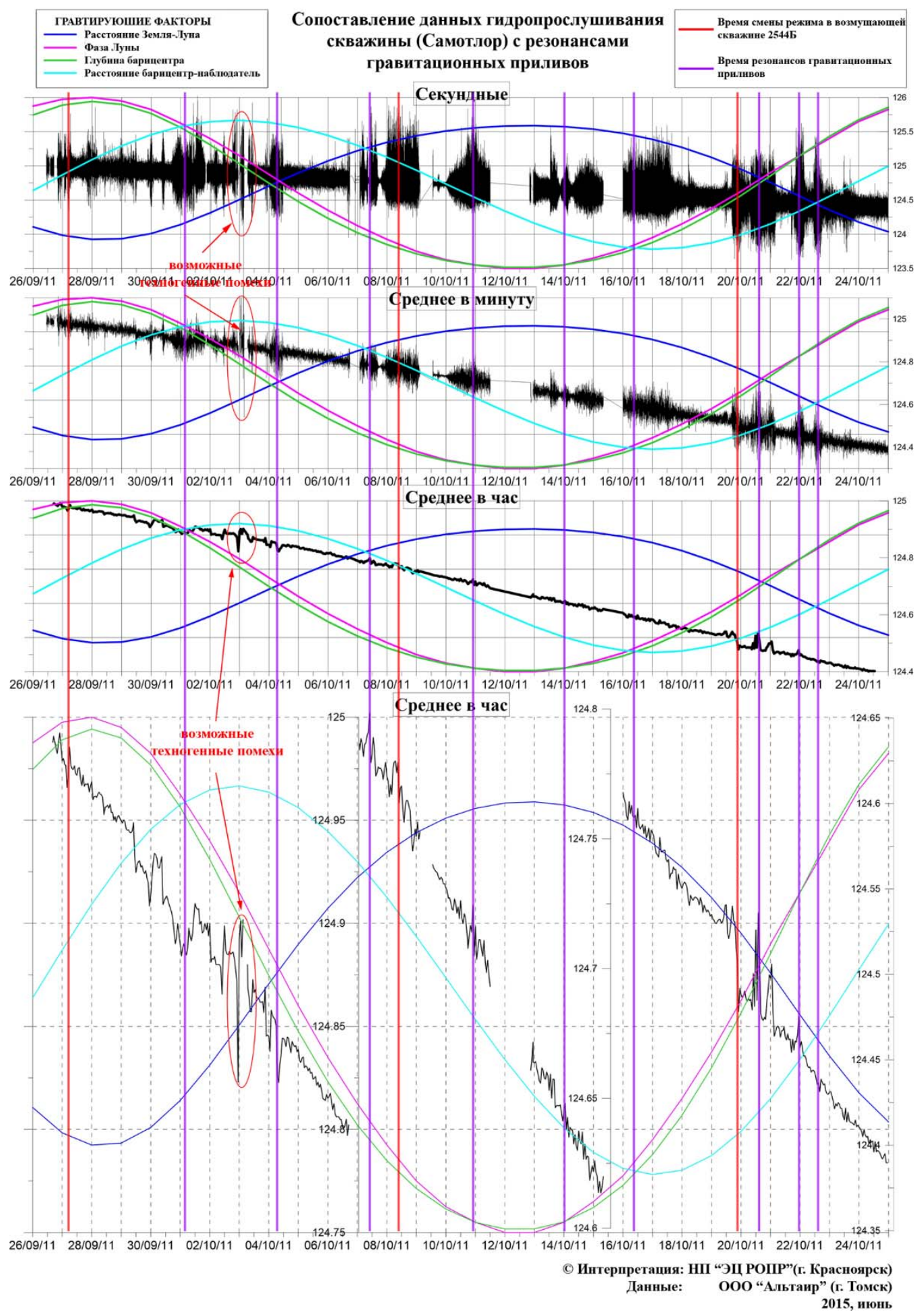

Рис. 16. Сопоставление данных гидропрослушивания скважины на Самотлорском месторождении с резонансами гравитационных приливов*

*Наблюдается устойчивая корреляция между шумами, возникающими в нефтяном пласте, и резонансами гравитационных приливов. Только в зоне «возможной техногенной помехи» уровень шумов в пласте связан, повидимому, не с резонансом приливов, а с неизвестным воздействием 
охватывают огромные массы геологической среды, включая не только земную кору, но и верхнюю мантию. В результате периодически в земной коре, литосфере и верхней мантии возникают аномальные напряжения, которые неизбежно влияют на различные геодинамические процессы (разрядку очагов землетрясений, усиление собственных колебаний НГЗ, перемещение пластичных масс в мантии с формированием плюмов и т.д.).

В частности, в опубликованной в Nature Geoscience статье [18] по результатам лабораторного моделирования предполагается, что на глубине около 1400 км происходит аномальное (в 2-3 раза) уплотнение - увеличение вязкости ферросиликатов вещества мантии (рис. 17). Именно в этом интервале глубин колеблется барицентр в течение лунного месяца.

На глубинах около 1500 км горное давление достигает от 20 до 60 ГПа или от 200 до 600 тыс. атм. При резонансах приливов и барицентра можно ожидать скачки давления (по отношению к горному давлению на этих глубинах) не менее 1,5-5 \%, т.е. от 2 до 30 тыс. атм.

Известно, что для получения искусственных алмазов необходима температура от 1000 до $2000{ }^{\circ} \mathrm{C}$ и давление в 20-60 тыс. атм. Эти «алмазные» величины давления вполне сопо-
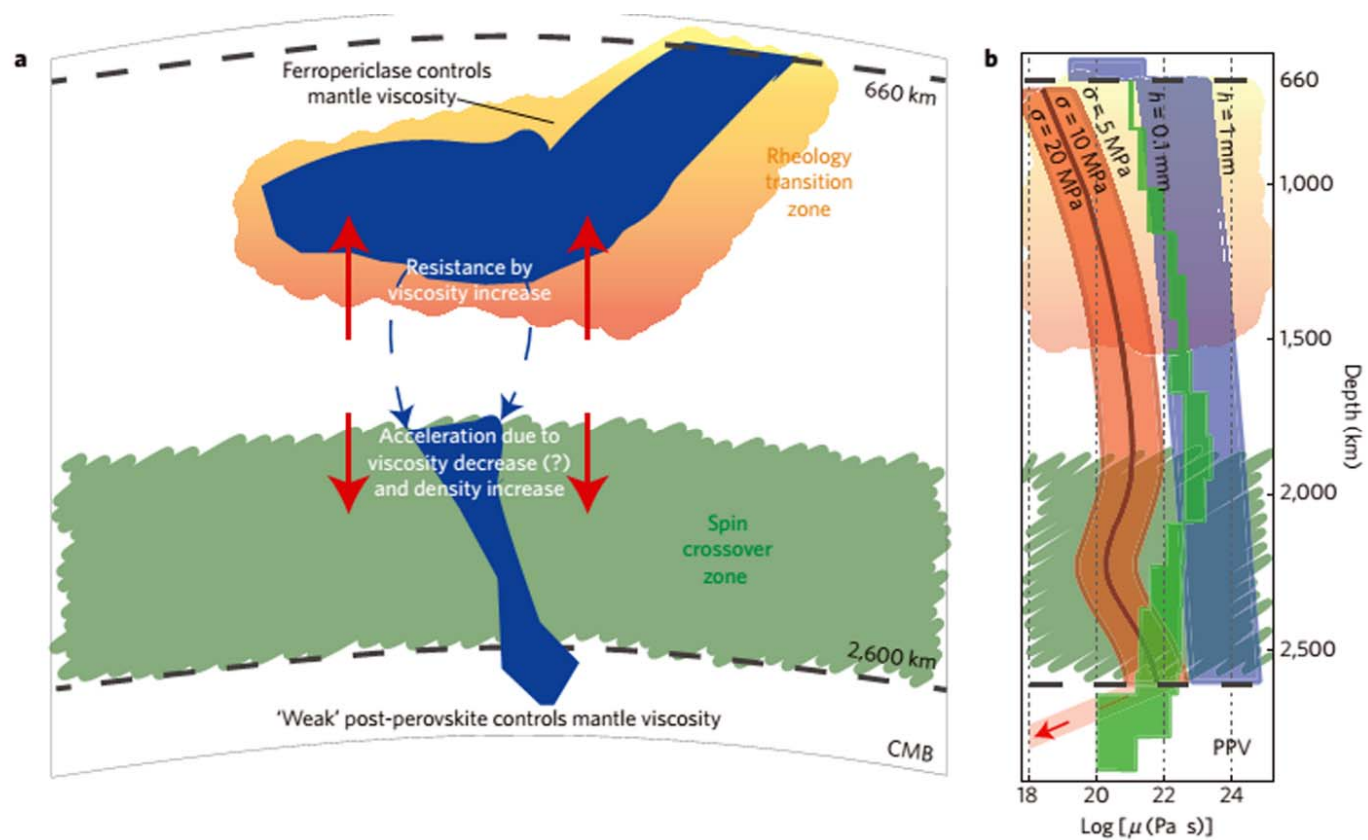

Рис. 17. Субдуктивная плита в нижней мантии и профили эффективной вязкости: $\mathbf{a}-$ изображение субдуктивной плиты в нижней мантии Земли. Синим выделена субдуктивная плита. Синие стрелки плита может преодолеть барьер вязкости и продолжать погружение в глубокий слой нижней мантии. Красные стрелки - иллюстрация влияния профиля эффективной вязкости на погружающуюся плиту. $\mathrm{CMB}$ - граница мантия-ядро; $\mathbf{b}$ - профили эффективной вязкости ( $\mu$ ). Красный: смоделированный профиль вязкости в зонах высокой деформации, рассчитанный для трех различных значений напряжения $о$ : Синий: смоделированный профиль вязкости в зонах с низким уровнем деформации, рассчитанный для двух различных значений степени детализации h. Существует предположение о резком повышении вязкости на два порядка на глубине 660 км. Слабый пост-перовскит (PPV) может привести к снижению вязкости мантии в зонах с высокой деформаций, показанных стрелкой в части b. Зеленый: прогнозируемый профиль вязкости на основании сравнения инверсии конвекции и данных об изостатической компенсации. PPV - пост-перовскит 
ставимы с условиями, которые возникают при перемещении барицентра в верхней мантии.

Колебания барицентра и резонансы приливов, вероятно, обусловливают перемещение вещества мантии с образованием известных в теории «плюмов». Колебания барицентра, несомненно, играют важную роль в латеральной миграции флюидов (включая нефть и газ) в земной коре. В нефтегазоносных бассейнах (Западная Сибирь, Тимано-Печорский и др.) преимущественно нефтяные залежи расположены к югу от более северных преимущественно газовых месторождений.

Это обстоятельство можно объяснить с позиций колебаний напряжений в земной коре под влиянием перемещения барицентра внутри тела Земли - более подвижный газ смещается в Северном полушарии на север по отношению к менее «подвижным» нефтяным залежам. Поэтому целесообразно учитывать геодинамические процессы при разработке теории формирования залежей нефти и газа.

\section{Заключение}

Исходя из вышеизложенного можно утверждать следующее:

1. Резонансы гравитационных приливов - значимый энергетический источник геодинамических процессов в земной коре. Резонансы приливов - основной триггерный фактор для возникновения сильных (M>5.0) землетрясений. Энергия резонанса приливов достаточна для возбуждения стоячих волн в НГЗ, что позволило предложить технологию прямых поисков нефти и газа - ФРС (РПВНГЗ) [14].

2. В практике нефтегазовой отрасли многие явления можно объяснить с позиций резонансной геодинамики. В частности, известно, что периодически на нефтегазовых промыслах случаются аварии - поломки труб внутри горной среды. Если исключить человеческий фактор, то причины аварий связаны с геодинамическими подвижками, возникающими при резонансах гравитационных приливов. Отсюда следует целесообразность не только изучения и теоретического осмысления механизмов резонансов гравитационных приливов в земной коре, но и использования мощного, устойчивого и предсказуемого энергетического источника (резонанса приливов) в горно-геологической практике: от прямого прогноза залежей нефти и газа до оптимизации технологических режимов испытаний, отбора нефти и газа, соблюдения геодинамической безопасности на промыслах.

3. Колебания давления в горных породах неизбежно сопровождаются сейсмоэлектрическим эффектом. Отсюда следует потенциальная возможность разработки технологии поиска месторождений твёрдых полезных ископаемых на основе использования энергии резонансов гравитационных приливов.

4. Целесообразно оценить возможную роль резонансов в формировании одиночных деформационных волн типа солитонов (основа так называемого тектонического оружия), что позволит прогнозировать «волны-убийцы» не только в океанах, но и в земной коре для обеспечения безопасности крупных техногенных сооружений (плотины и др.). Таким образом, мониторинг и учёт резонансов гравитационных приливов позволяет объяснять и прогнозировать многие практически важные геодинамические процессы в земной коре и литосфере Земли.

$$
-163-
$$




\section{Благодарности}

Авторы выражают благодарность члену-корреспонденту РАН Владимиру Викторовичу Шайдурову за поддержку исследований, Геннадию Яковлевичу Дидичину и Ольге Васильевне Гутиной за помощь в получении геолого-геофизических материалов, использованных в работе.

\section{Список литературы}

[1] Геофизические методы исследования / под ред. Н.И. Селиверстова. ПетропавловскКамчатский, 2004, 232 с. [Geophysical research methods. Ed. By N.I.Seliverstov. PetropavlovskKamchatskii, 2004, 232 p. (in Russian)]

[2] Лыгин А.М., Стажило-Алексеев С.К., Кадурин И.Н. и др. Мониторинг напряжённодеформированного состояния геологической среды в Сибирском и Дальневосточном федеральных округах в 2007-2014 годах. Красноярск: Город, 2015, 114 с. [Lygin A.M., StazhiloAlekseev S.K., Kadurin N.N. Monitoring the stress-strain state of geological environment in the Siberian and Far Eastern Federal districts in 2007-2014 years. Krasnoyask, Gorod, 2015, 114 p. (in Russian)]

[3] Ржонсницкий В.Б. Приливные движения. Л.: Гидрометеоиздат, 1979, 244 с. [Rzhonsnitskii V.B. Tidal movement, Leningrad, Gidrometeoizdat, 1979, 244 p. (in Russian)]

[4] Мельхиор П. Земные приливы. М.: Мир, 1968, 482 с. [Melkhior P. The Earth's tides, Moscow, Mir, 1968, 482 p. (in Russian)]

[5] Пустовитенко Б.Г., Лущик А.В., Боборыкина О.В. и др. Мониторинг сейсмических процессов в Крымско-Черноморском регионе. Севастополь: НПЦ «ЭКОСИ Гидрофизика», 2014, 264 c. [Pustovitenko B.G., Lishchik A.V., Boborykina O.V. et. al. Monitoring of seismic processes in the Crimean-Black Sea region. Sevastopol, EKOSI Gidrofizika, 2014, 264 p. (in Russian)]

[6] Сибгатулин В.Г., Перетокин С.А., Симонов К.В., Кабанов А.А. Информационное и алгоритмическое обеспечение системы наблюдений флюидных геообъектов. Pаспределенные информационные $и$ вычислительные ресурсы: материалы ХІІІ Российской конференции с участием иностранных ученых. Новосибирск, 2010 [Sibgatulin V.G., Peretokin S.A., Simonov K.V., Kabanov A.A. Information and algorithmic support of the observing system fluid geoobjects. Distributed information and computing resources, Novosibirsk, 2010 (in Russian)]

[7] Лаборатория реактивного движения Калифорнийского технологического института, http://ssd.jpl.nasa.gov/ [The jet propulsion laboratory, California Institute of technology]

[8] Sibgatulin V.G., Peretokin S.A., Kabanov A.A. Resonances of gravitational tides and their effect on geological environment. Earth science frontiers, 2014, 21(4), 303-310.

[9] http://earthquake.usgs.gov/earthquakes/world/world_deaths.php

[10] Беседина А.Н., Виноградов Е.А., Горбунова Э.М. и др. Отклик флюидонасыщенных коллекторов на лунно-солнечные приливы. Ч. 1. Фоновые параметры приливных компонент в смещении грунта и уровне подземных вод. Физика Земли, 2015, 1, 73-82 [Besedina A.N., Vinogradov E.A., Gorbunova E.M. et. al. The response of fluid-saturated reservoirs at the lunar-solar tides. Ch. 1. Background parameters tidal component in the ground movement and groundwater level. Fizika Zemli, 2015, 1, 73-82 (in Russian)] 
[11] Авсюк Ю.Н. Приливные сильь и природные процессьь. М.: Объединённый институт физики Земли им. О.Ю. Шмидта СО РАН, 1996, 186 с. [Avsiuk Iu.N. Tidal forces and natural processes. Moscow, 1996, 186 p. (in Russian)]

[12] Сибгатулин В.Г., Кабанов А.А. Мониторинг НДС геологической среды на основе регистрации резонансов гравитационных приливов. Геодинамические поля и оценка современного состояния объектов использования атомной энергии: сб. докл. науч.-техн. конф. Железногорск, 2013, с. 92-96 [Sibgatulin V.G., Kabanov A.A. The VAT monitoring of the geological environment on the basis of registration of the resonances of gravitational tides. Geodynamic fields and assessment of the current state of objects of use of atomic energy, Zheleznogorsk, 2013, p. 92-96 (in Russian)]

[13] Дидичин Г.Я., Сибгатулин В.Г., Перетокин С.А., Гутина О.В. Повышение эффективности прогноза нефтегазовых залежей на основе изучения реакции геофизических и геохимических полей на гравитационные приливы в земной коре. Геология и минерально-сырьевые ресурсы Сибири, 2011, 2, 38-46 [Didichin G.Ia., Sibgatulin V.G., Peretokin S.A., Gutina O.V. Improving the efficiency of forecast of oil and gas deposits based on the study of the response of geophysical and geochemical fields on the gravitational tides in the earth's. Geology and mineral resources of Siberia, 2011, 2, 38-46 (in Russian)]

[14] Сибгатулин В.Г., Дидичин Г.Я., Перетокин С.А., Кабанов А.А. Резонансы гравитационных приливов в земной коре и их влияние на нефтегазовые залежи. Нефть. Газ. Новаиии. Самара: Типография ООО «Издательский дом «Агни», 2014, 1, 14-19 [Sibgatulin V.G., Didichin G.Ia., Peretokin S.A., Kabanov A.A. The resonances of gravitational tides in the earth's crust and their influence on oil and gas deposits. Oil. Gas. Innovatns, 2014, 1, $14-19$ (in Russian)]

[15] Биряльцев Е.В. Вильданов А.А., Еронина Е.В.и др. Моделирование эффекта АНЧАР в методе низкочастотного сейсмического зондирования. Технология сейсморазведки, 2010, № 1, 31-40 [Birialtsev E.V., Vildanov A.A., Eronina E.V. et. al. Modeling of the effect in the method ANCHAR low-frequency seismic sounding. The technology of seismic, 2010, №1, 31-40 (in Russian)]

[16] Кузнецов О.Л., Арутюнов С.Л., Востров Н.Н. и др. Российская инфразвуковая технология АНЧАР: уникальная практика разведки и освоения нефтяных и газовых ресурсов Международная геофизическая конференция, тезисы докладов. СПб., 2000 [Kuznetsov O.L., Arutiunov S.L., Vostrov N.N. et. al. Russian infrasound technology ANCHAR: * unique experience in the exploration and development of oil and gas resources. International geophysical conference, St. Petersburg, 2000 (in Russian)]

[17] Wenzel H.G. Earth tide analysis package ETERNA 3.0 BIM, 1994, 118, 8719-8721.

[18] Hauke Marquardt, Lowell Miyagi Slab stagnation in the shallow lower mantle linked to an increase in mantle viscosity. Nature Geoscience, 2015, 8,311-314. 